\title{
Paramarteilia canceri sp.n. (Cercozoa) in the European edible crab (Cancer pagurus) with a proposal for the revision of the order Paramyxida Chatton, 1911
}

\author{
Stephen W. Feist ${ }^{1}$, P. Mike Hine ${ }^{2}$, Kelly S. Bateman ${ }^{1}$, Grant D. Stentiford ${ }^{1}$ and Matt Longshaw ${ }^{1}$ \\ ${ }^{1}$ Centre for Environment, Fisheries and Aquaculture Science (Cefas), Weymouth Laboratory, Barrack Road, The Nothe, \\ Weymouth, Dorset DT4 8UB, UK; \\ ${ }^{2} 73$ rue de la Fée au Bois, 17450 Fouras, France
}

\begin{abstract}
A new species, Paramarteilia canceri sp. n., is described using light and electron microscopy from the edible crab Cancer pagurus L. captured from the English Channel. No external symptoms were noted, although infected animals were typically lethargic and unresponsive to external stimuli. Organs of infected animals were shrunken and collapsed compared with apparently healthy individuals. Although the infection was systemic, marked host responses were only noted in the hepatopancreas where the parasite induced a pronounced haemocytic infiltration. Prevalence of infection throughout the study was $1.1 \%$, with a maximum monthly prevalence of $3 \%$. The intracellular parasite was typically $15 \mu \mathrm{m}$ in length and composed of a primary cell containing up to three secondary cells derived by internal cleavage. Each secondary cell contains two bicellular spores. The parasite is readily differentiated from the other described paramyxean species by a combination of the number of secondary and tertiary cells. In light of this new discovery, a revision of the order Paramyxida Chatton, 1911 is proposed based upon comparison to the original descriptions of this parasite group in various species of invertebrate hosts. The proposed classification is based on the number of cells within the spores (tertiary cells), so that only three genera remain within the order, namely Marteilia Grizel, Comps, Bonami, Cousserans, Duthoit et Le Pennec, 1974, Paramarteilia Ginsburger-Vogel et Desportes, 1979 and Paramyxa Chatton, 1911. Subsequent discrimination of species is based on a combination of the number of secondary cells within the primary cell and the number of tertiary cells within secondary cells. It is proposed that the genus Marteilioides Comps, Park et Desportes, 1986 is suppressed and the type species of the genus, M. chungmuensis Comps, Park et Desportes, 1986, is transferred to Marteilia and that the other representative of the genus, M. branchialis Anderson et Lester, 1992, is transferred to Paramarteilia. Further, Paramyxoides Larsson et Køie, 2005 is considered as a junior synonym of Paramyxa and its type and only species, Paramyxoides nephtys Larsson et Køie, 2005, is transferred to Paramyxa.
\end{abstract}

Key words: Paramarteilia canceri, Paramyxea, Paramyxida, Cercozoa, Paramyxa, Paramyxoides, Marteilioides, Marteilia, ultrastructure, Cancer pagurus

The European edible crab (Cancer pagurus L.) supports an important fishery in the United Kingdom, worth approximately 37 million Euros annually. Despite its commercial significance, there is only limited information on the diseases affecting this species (reviewed by Stentiford 2008). Infections with Hematodinium sp. giving rise to the condition 'Pink crab disease' (PCD) have been described in stocks in the English Channel (Stentiford et al. 2002). More recently, a new genus and species of microsporean parasite (Enterospora canceri Stentiford, Bateman, Longshaw et Feist, 2007) has also been found infecting connective tissues (Stentiford et al. 2007) and a viral infection affecting juvenile crabs has also been reported (Bateman and Stentiford 2008). During a histopathological survey of edible crabs from Guernsey and
English Channel localities close to Weymouth and Portland an unusual infection with a paramyxid parasite was discovered.

The order Paramyxida Chatton, 1911 has been the subject of a number of revisions in particularly being referred to as the phylum Paramyxea Desportes et Perkins, 1990. Following a number of iterations to restructure the protists, the most stable taxonomy proposed is that the order Paramyxida resides within the class Ascetosporea Sprague, 1979 and the phylum Cercozoa Cavalier-Smith, 1998 (Cavalier-Smith and Chao 2003). The order Paramyxida currently contains five genera. Their representatives are metazoan parasites characterised by the production of variable numbers of 'daughter cells' formed by endogeny within a primary cell, leading via a series of further cell di- 
visions to the formation of spores (Desportes and Perkins 1990). Members of the genera Marteilia Grizel, Comps, Bonami, Cousserans, Duthoit et Le Pennec, 1974 and Marteilioides Comps, Park et Desportes, 1986 are parasites of marine bivalve molluscs and some species, such as Marteilia refringens Grizel, Comps, Bonami, Cousserans, Duthoit et Le Pennec, 1974 and Marteilia sydneyi Perkins et Wolf, 1976, are important pathogens causing mass mortalities in the European flat oyster (Ostrea edulis) and the Sydney rock oyster (Saccostrea glomerata [syn. S. commercialis]) respectively (Berthe et al. 2004). Both of these species are listed in the World Organisation for Animal Health (Office International des Epizooties (OIE), International Aquatic Animal Health Code (OIE 2006). In addition, Marteilioides chungmuensis Comps, Park et Desportes, 1986 is a significant pathogen affecting the ovary of Pacific oyster (Crassostrea gigas) (Comps et al. 1986, 1987). Of the remaining genera, Paramyxa Chatton, 1911 and Paramyxoides Larsson et Køie, 2005 have been described from polychaetes (Desportes 1981, Larsson and Køie 2005) and Paramarteilia GinsburgerVogel et Desportes, 1979, which contains a single species (Paramarteilia orchestiae Ginsburger-Vogel et Desportes, 1979), has been described from the amphipod crustacean Orchestia gammarellus (Ginsburger-Vogel and Desportes 1979a,b). This parasite infects the testes and ovary of its host and produces chitinous nodules under the epidermis. Growth and reproduction appear unaffected. However, Ginsburger-Vogel (1991) demonstrated that $P$. orchestiae infections are associated with intersex condition in male O. gammarellus and experimentally in two other Orchestia species. The genus Paramarteilia is currently distinguished from other paramyxeans by the presence of two bicellular spores in each secondary cell (sporont), rather than a combination one, two or four bi-, tri- or tetracellular spores in the other genera. Here we report the first description of an infection with a new species, Paramarteilia canceri in a decapod crustacean, the European edible crab, and provide a proposal for a simplified taxonomy of the order Paramyxida.

\section{MATERIALS AND METHODS}

Sixteen European edible crabs (Cancer pagurus) were captured from the south coast of Guernsey (UK Channel Islands; $49^{\circ} 24^{\prime} \mathrm{N}, 2^{\circ} 32^{\prime}$ to $2^{\circ} 43^{\prime} \mathrm{W}$ ) in November 2001 . Thirty edible crabs, male and female, were collected each month between December 2003 and November 2004 from the fishery based around Weymouth and Portland, UK using conventional baited parlour pots $\left(50^{\circ} 30^{\prime} \mathrm{N}, 2^{\circ} 27^{\prime} \mathrm{W}\right)$. One hundred and sixty female crabs were sampled in July 2007 from the same location. In addition, C. pagurus were sampled from the fishery in the South Kimmeridge Bay region of Dorset, United Kingdom $\left(50^{\circ} 36^{\prime} \mathrm{N}\right.$, $\left.2^{\circ} 8^{\prime} \mathrm{W}\right)$. Dispensation licences from the United Kingdom Marine Fisheries Agency (Council Regulation 850/98) allowed for the sampling of legally undersized (carapace width, CW, $<140 \mathrm{~mm}$ ) and legal-sized $(\mathrm{CW}>140 \mathrm{~mm})$ crabs, both from the fishery off
South Kimmeridge Bay and from the shoreline directly inshore from the fishery site. One hundred and fifty $C$. pagurus were sampled (60 with $\mathrm{CW}<100 \mathrm{~mm}, 50$ with $\mathrm{CW}>100$ and $<140$ $\mathrm{mm}$, and 40 with $\mathrm{CW}>140 \mathrm{~mm}$ ).

Histology. Crabs were anaesthetised by chilling on ice for $30 \mathrm{~min}$ before dissection. Hepatopancreas, gill, gonad, heart and body muscle were excised and placed immediately into Davidson's seawater fixative for $24 \mathrm{~h}$, then transferred to $70 \%$ industrial methylated spirit. Samples were infiltrated with paraffin under vacuum using standard protocols. Sections were cut at a thickness of 3-5 $\mu \mathrm{m}$, mounted onto glass slides, and stained with haematoxylin and eosin (H\&E). Stained sections were analysed by light microscopy (Nikon Eclipse E800); digital images and measurements were obtained using the Lucia ${ }^{\mathrm{TM}}$ Screen Measurement System (Nikon, UK).

Electron microscopy. The hepatopancreas and gonad were removed; small blocks of tissue $\left(2 \mathrm{~mm}^{3}\right)$ were fixed in $2.5 \%$ gluteraldehyde in $0.1 \mathrm{M}$ sodium cacodylate buffer $(\mathrm{pH} 7.4)$ for $2 \mathrm{~h}$ at room temperature. Fixed tissue samples were rinsed in $0.1 \mathrm{M}$ sodium cacodylate buffer $(\mathrm{pH} 7.4)$ and post-fixed for $1 \mathrm{~h}$ in $1 \%$ osmium tetroxide in $0.1 \mathrm{M}$ sodium cacodylate buffer. Specimens were washed in three changes of $0.1 \mathrm{M}$ sodium cacodylate buffer before dehydration through a graded acetone series. Specimens were embedded in Agar 100 epoxy resin (Agar Scientific, Agar 100 pre-mix kit medium) and polymerised overnight at $60^{\circ} \mathrm{C}$ in an oven. Semithin $(1-2 \mu \mathrm{m})$ sections were stained with Toluidine Blue for viewing with a light microscope to identify suitable target areas. Ultrathin sections $(70-90 \mathrm{~nm})$ of target areas were mounted on uncoated copper grids and stained with uranyl acetate and Reynolds' lead citrate (Reynolds 1963). Grids were examined using a JEOL JEM 1210 transmission electron microscope and digital images captured using a Gatan Erlangshen ES500W camera and Gatan Digital Micrograph ${ }^{\mathrm{TM}}$ software. Stained sections from infected edible crabs were deposited in the Registry of Aquatic Pathology (RAP), Cefas Weymouth and in the collection of the Institute of Parasitology, Academy of Sciences of the Czech Republic, České Budějovice.

\section{RESULTS}

\section{Clinical signs and histopathology}

A total of 686 crabs were examined for the presence of the parasite, with maximum prevalence being 3\% during January and February 2004. Eight animals were diagnosed as infected with the paramyxean parasite with 1 crab from Guernsey, 5 crabs infected in coastal locations around Weymouth and Portland and 2 infected crabs from South Kimmeridge Bay. Infections occurred in the crabs collected in January, February, October and November 2004 and in July 2007 only. External signs of infection were absent although crabs harbouring the infection were lethargic and unresponsive. Internally, developmental stages of the parasite appeared to be systemic, being detected in several organs and tissues including the hepatopancreas, gill, heart, skeletal muscle, tegmental gland and gonads as well as within congested haemal sinuses. Most parasites were seen in the hepatopancreas associated with an influx of haemocytes and fibroblast-like cells 

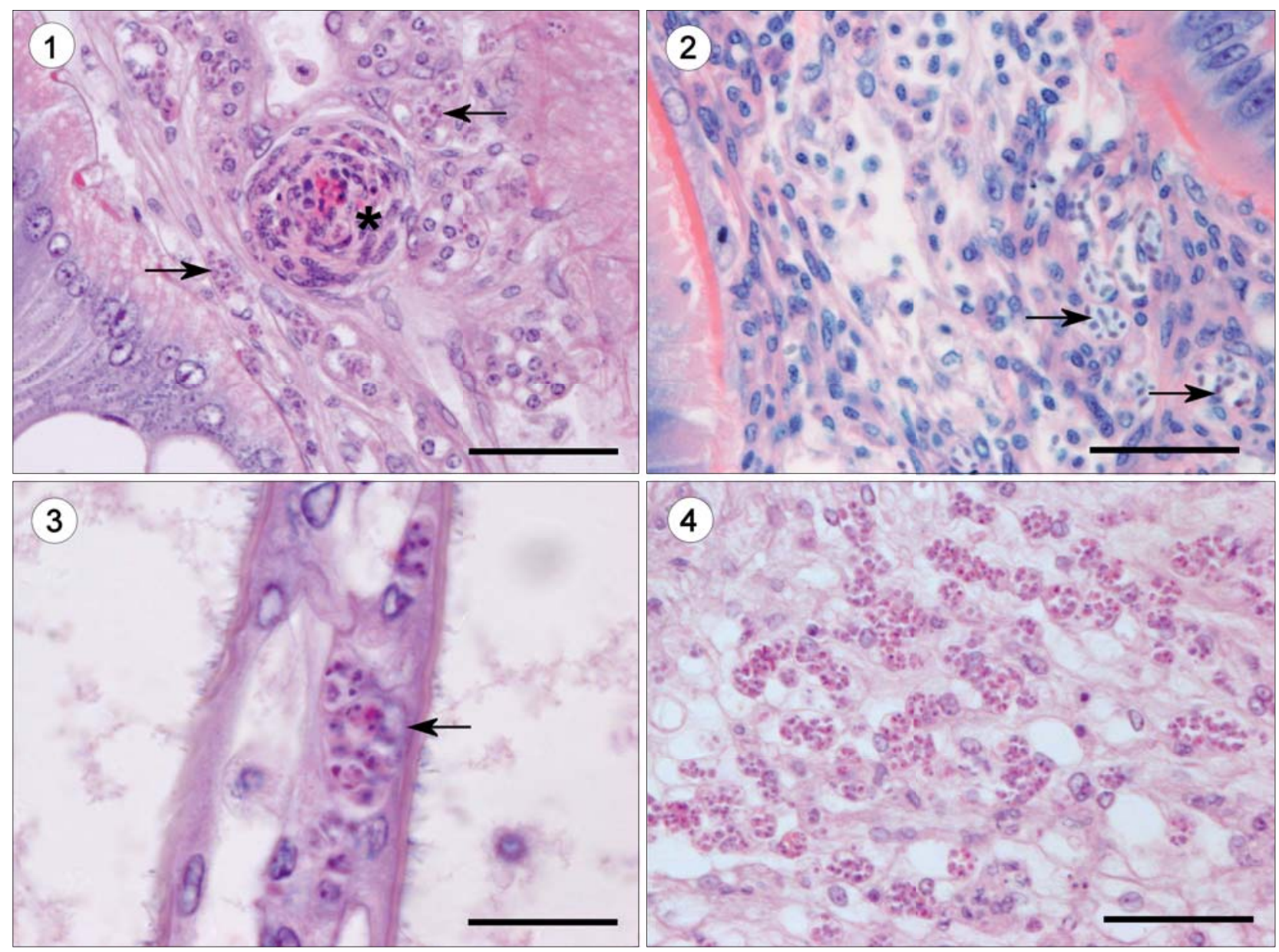

Figs. 1-4. Light micrographs of Cancer pagurus tissues infected with Paramarteilia canceri sp. n. Fig. 1. Granulomatous response (asterisk) within haemal sinuses of the hepatopancreas. Parasites are present throughout the tissue (arrows). H\&E. Fig. 2. Co-infection with a yeast-like organism in the haemal sinuses of the hepatopancreas (arrows). H\&E. Fig. 3. High power view of parasites infecting the gill epithelium (arrow). H\&E. Fig. 4. Infected spongy cells in the pericardium of the heart. H\&E. Scale bars: Figs. 1, $2,4=50 \mu \mathrm{m}$; Fig. $3=100 \mu \mathrm{m}$.

eventually resulting in encapsulation (Fig. 1). In a single specimen, a co-infection with a yeast-like organism similar to that described by Stentiford et al. (2003) was detected (Fig. 2). In the gills, thickening of the respiratory epithelium was associated with haemocyte infiltration (Fig. 3). Large numbers of parasites were observed in the pericardial tissues, but haemocyte infiltration and necrosis of host cells were largely absent (Fig. 4). The nerves, including major nerves serving the claw muscles were infected. From histology it was not possible to determine if the parasites were located within nerve cells or were intercellular (Fig. 5). Again, host response was largely absent with little evidence of nerve cell degeneration or necrosis. Particularly heavy infections were found in the vas deferens of a single animal collected in July 2007. Large numbers of parasites were present in the connective tissues supporting the tall columnar epithelium with migration through the epithelium towards the lumen (Fig. 6). Despite the presence of numerous parasites the epithelium remained intact, suggesting that the parasites were intercellular. However, they were often seen to be intracellular within haemocytes, fixed phagocytes, connective tissue cells, ova and even developing spermatocytes (Figs. 7, 8). Some appeared to be extracellular in affected tissues and were likely to have been released from ruptured host cells.

\section{Ultrastructure}

The earliest stage detected consisted of a primary cell containing a single secondary cell intracellularly within epithelial cells (Fig. 9). The primary cell increased in size to accommodate secondary cell division. Although most primary cells examined contained only one nucleus, a single example appeared to contain two nuclei (Fig. 10). The nucleoplasm contained uniformly granular chromatin and a prominent nucleolus observed in a single case (Fig. 10). The plasma membrane of the primary cell was smooth and devoid of pseudopodia-like projections. The primary cell cytoplasm was finely granular with free ribosomes 

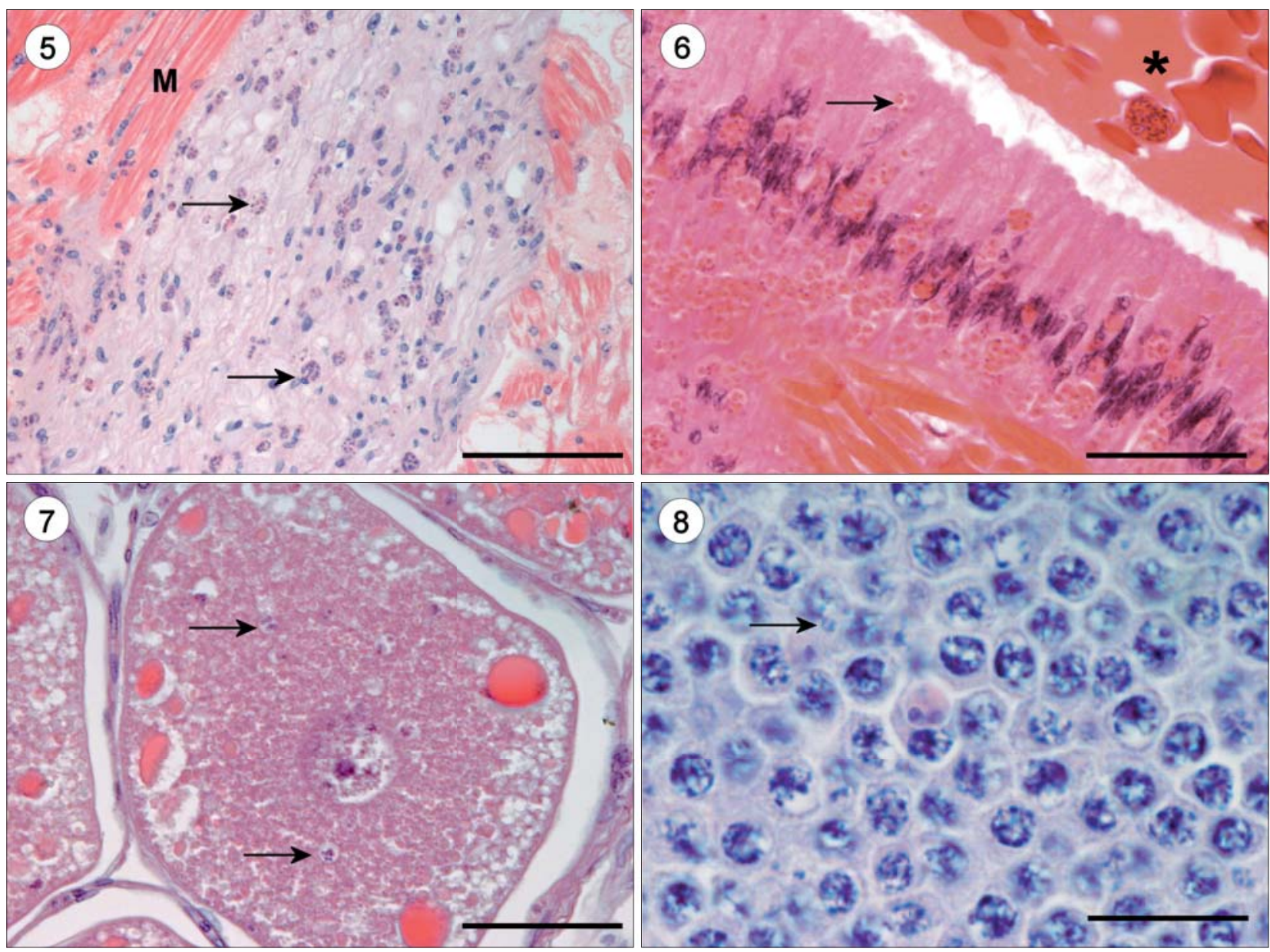

Figs. 5-8. Light micrographs of Cancer pagurus tissues infected with Paramarteilia canceri sp. n. Fig. 5. Multiple parasite stages (arrows) infecting a nerve fibre running through the claw muscle (M). H\&E. Fig. 6. Multiple parasite stages infecting the epithelium of the vas deferens. Parasites can be seen apparently migrating through the basal and nuclear regions of the epithelium towards the lumen of the duct. Proteinaceous fluid and spermatophores are present in the lumen (asterisk). H\&E. Fig. 7. Infected early vitellogenic oocyte containing several small parasite stages (arrows). H\&E. Fig. 8. Infected spermatogonial cell (arrow). H\&E. Scale bars: Figs. 5-7= $100 \mu \mathrm{m}$; Fig. $8=50 \mu \mathrm{m}$.

and contained numerous electron-dense haplosporosomes. These were cylindrical, bacilliform, usually with a rounded end when mature, measuring $\sim 280 \mathrm{~nm}$ in length and $50 \mathrm{~nm}$ in width. They were found throughout the cytoplasm but were observed in high concentrations associated with membranous structures and vesicles containing granular material as in multivesicular bodies of other paramyxids and in haplosporidians. These are the sites of haplosporogenesis (Fig. 11). In longitudinal section they consisted of an outer and inner membrane, separating the cortex and medulla (Fig. 12). In maturing primary cell haplosporosomes, one end was empty and the membranes folded, suggesting that these structures may exceed $280 \mathrm{~nm}$ in length. The cytoplasm also contained sparse endoplasmic reticulum (ER), mitochondria containing few cristae, small vesicles, membranous whorls and large apparently empty vacuoles (Fig. 13). Up to three secondary cells were present in sections of "mature" parasites (Fig. 13).
The structure of the secondary cell changed during growth. Initially, they appeared as small $(3.9 \mu \mathrm{m}$ in diameter $)(n=2)$ cells with a large nucleus occupying most of the cytoplasm (Fig. 14). In all stages the plasma membrane of the secondary cell appeared smooth and devoid of pseudopodia-like projections. The secondary cell nucleus had a smooth envelope with occasional conspicuous nuclear pores, clearly visible where the nuclear membrane and the surrounding cytoplasm were separated. The nucleoplasm was uniformly granular, pale staining with a conspicuous nucleolus. Occasionally, the initial stage of cell division was observed with the centriole associated with an indentation in the nuclear membrane (Fig. 14). The cytoplasm was granular with sparse strands of ER, a single mitochondrion and small vesicles (Fig. 15). A dense granular structure was occasionally adjacent to the nucleus and when observed, the cytoplasm contained microtubules (Fig. 16). Secondary cells appeared devoid of haplosporosomes. As the secondary cell increased to 

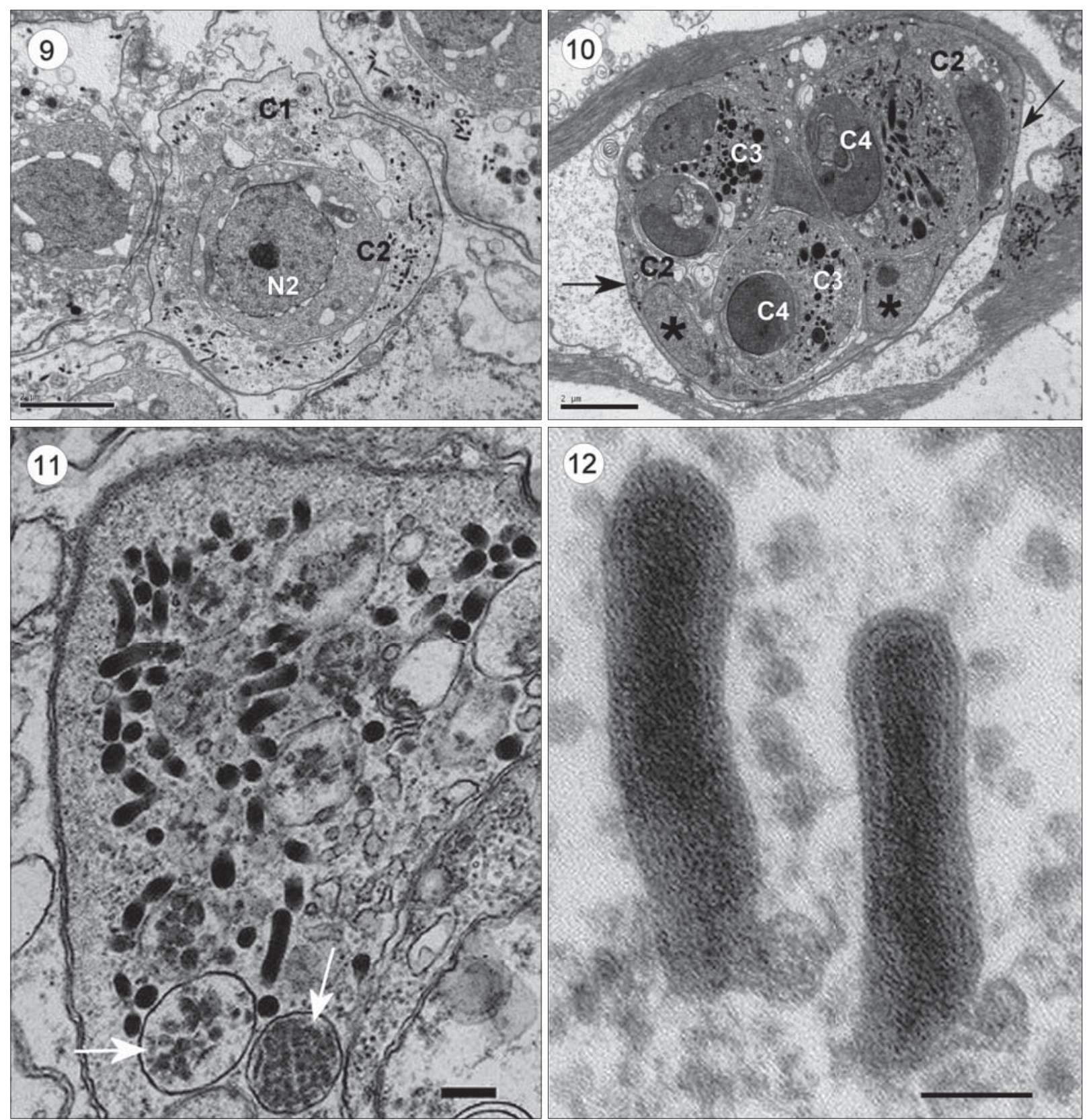

Figs. 9-12. Transmission electron micrographs of Paramarteilia canceri sp. n. infecting Cancer pagurus. Fig. 9. Earliest identified stage of $P$. canceri is a primary cell $(\mathrm{C} 1)$ containing a single secondary cell $(\mathrm{C} 2)$. The cytoplasm of the primary cell is interspersed with bacilliform haplosporosomes and large vacuoles. The nucleus (N2) of the secondary cell contains a prominent central nucleolus and numerous nuclear pores around the periphery. Fig. 10. Developing primary cell (arrow) containing two secondary cells (C2) enclosing tertiary cells (C3) with prominent haplosporosomes and quaternary cells (C4). The primary cell apparently contains two nuclei $(*)$, one with a prominent nucleolus. Fig. 11. High power view of primary cell cytoplasm showing putative haplosporogenesis denoted by the presence of membranous structures and granular-filled vesicles (multivesicular bodies) (arrows) as well as several electron-dense haplosporosomes. Fig. 12. Longitudinal section through bacilliform haplosporosomes of the primary cell with outer and inner membranes separating the cortex and medulla. Scale bars: Figs. 9, $10=2 \mu \mathrm{m}$; Fig. $11=200 \mathrm{~nm}$; Fig. $12=60 \mathrm{~nm}$.

a diameter of $\sim 5.8 \mu \mathrm{m}(\mathrm{n}=5)$, it became a pansporoblast (=sporont) within which one or two tertiary cells were produced (Fig. 17). These constrained the nucleus to the periphery of the cell where it appeared triangular with dense chromatin (Figs. 17, 18). It is uncertain whether the nucleus divides although two nuclear sections within a secondary cell suggested that this may occur (Fig. 18). However, this was observed once, and may have been two profiles of a single attenuated nucleus due to compression by constrained tertiary cells.

Uninucleate tertiary (=sporal) cells were $<2.9 \mu \mathrm{m}$ $(n=10)$ in diameter occasionally with pseudopodia-like 


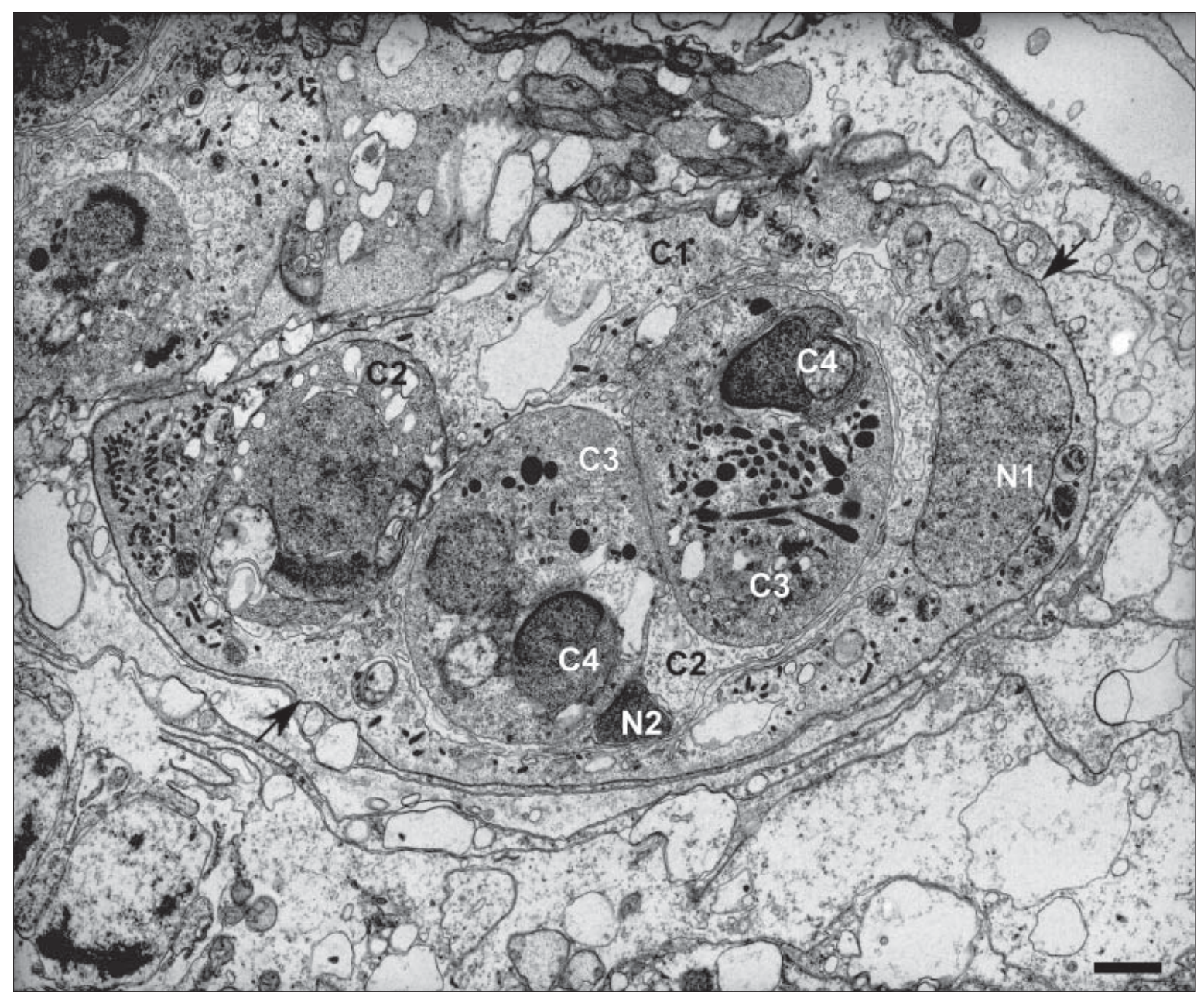

Fig. 13. Components of a typical large multicellular stage of Paramarteilia canceri sp. $n$. The primary cell (C1) is delineated from the surrounding tissues by a plasmalemma (arrows) and contains numerous electron-dense bacilliform haplosporosomes in the cytoplasm. Note also the presence of occasional multivesicular bodies and large, apparently empty vacuoles. The primary cell contains a prominent nucleus (N1) and two secondary cells (C2), one of which contains two tertiary cells (C3), each of which in turn enclose a single quaternary cell (C4). One of the secondary cells also contains a typical triangular nucleus (N2). Typically, the tertiary cells contain numerous prominent electron-dense haplosporosomes with bulbous ends. Scale bar $=1 \mu \mathrm{m}$.

projections from the plasma membrane and were characterised by abundant large haplosporosomes in their cytoplasm (Figs. 19-21). Nuclei were spherical with uniform fine chromatin and many nuclear pores (Fig. 20). Mitochondria were not observed. The cytosol was granular, with ribosomes, vacuoles $<1 \mu \mathrm{m}$ in diameter and strands of ER surrounding quaternary (=sporoplasm or germinative) cells. Haplosporogenesis was similar to observations on primary cells and included the formation of bacilliform haplosporosomes (Fig. 22). However, haplosporosomes $<3.5 \mu \mathrm{m}$ long with one end bulb-shaped, $\sim 500 \mathrm{~nm}$ in diameter and gradually tapering to a final diameter of $95.6 \mathrm{~nm}(\mathrm{n}=10)$, were also noted (Fig. 23). In longitudinal sections of the bulbous region the double membranes seen in the bacilliform forms were evident. At the apex, electron-dense material occurred against the internal membrane (Figs. 23-25), below which fibrillar material was arranged longitudinally along the length of the haplosporosome and surrounded by the inner membrane (Fig. 25). In transverse sections through the 'neck' of the bulbous region, the inner membrane was discontinuous and seen to curl inwards towards the central dense medulla of the haplosporosome (Fig. 25). This was not seen in transverse sections of the narrower parts of the haplosporosome, many of which appeared angular in profile.

Most tertiary cells contained a single quaternary cell within their cytoplasm. This was usually spherical but occasionally ovoid and $<1.9 \mu \mathrm{m}(\mathrm{n}=5)$ in diameter (Figs. 26-28). The cytoplasm contained many free ribosomes and a discrete dense accumulation of granular material (ribosomes?) similar to those in secondary cells and, a sparse ER. The nucleus was reniform in cross-section and contained a dense granular nucleoplasm with a single nucleolus (Fig. 26). It was peripheral against the plasmalemma where the close apposition of the nuclear and cell membranes gave the appearance of a markedly extended 

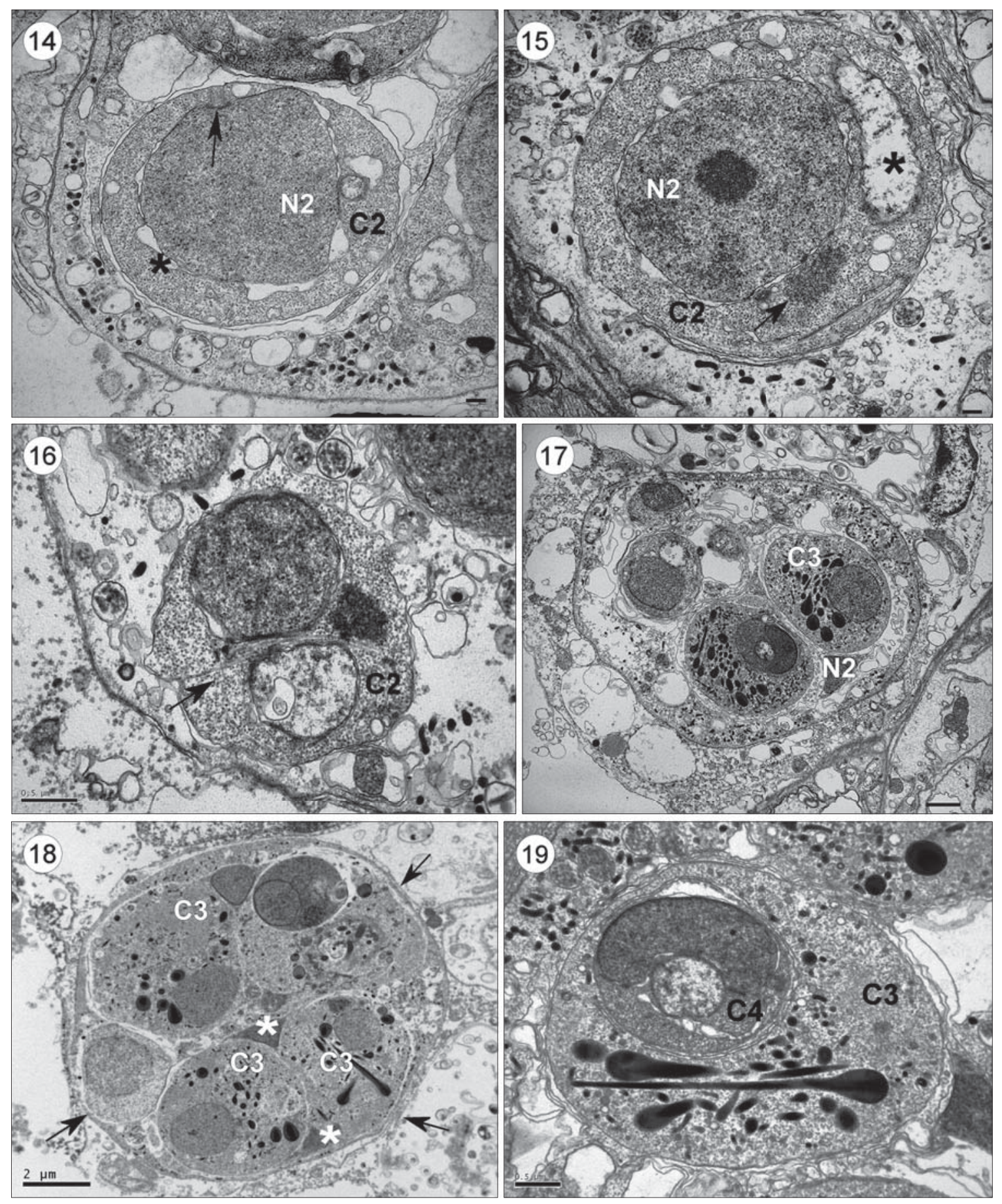

Figs. 14-19. Transmission electron micrographs of Paramarteilia canceri sp. n. infecting Cancer pagurus. Fig. 14. A secondary cell (C2) undergoing division. The large secondary cell nucleus (N2) occupies the majority of the cytoplasm and the nuclear membrane is interspersed with numerous nuclear pores visible as conspicuous separation of the nuclear membrane and the surrounding cytoplasm $(*)$. A centriole is visible in close proximity to the secondary cell nucleus (arrow). Fig. 15. Developing secondary cell (C2) containing a single mitochondrion $\left(^{*}\right)$ and numerous small vesicles. Occasionally, a dense granular structure (arrow) was noted in the secondary cell cytoplasm associated with the nucleus which may represent ribosomes. The nucleus (N2) contains a prominent nucleolus. Fig. 16. Further development and internal cleavage of the secondary cell (C2) with microtubules present in the cytoplasm (arrow). Fig. 17. Early pansporoblast (sporont) containing secondary cells and tertiary cells (C3) with typical electron-dense bulbous haplosporosomes. The nucleus of the secondary cell (N2) is constrained to the periphery of the secondary cell and assumes a triangular appearance in cross-section (see Fig. 13). Fig. 18. Further divisions within the secondary cells leads to production of two tertiary cells per secondary cell. Three secondary cells are visible in section (arrows). Note the two triangular profiles of the C2 nucleus $\left(^{*}\right)$. Fig. 19. Details of tertiary cell (C3) containing numerous electron-dense haplosporosomes and a single quaternary cell (C4). Scale bars: Figs. 14, 15, $17=200 \mathrm{~nm}$; Figs. 16, $19=0.5 \mu \mathrm{m}$; Fig. $18=2 \mu \mathrm{m}$. 

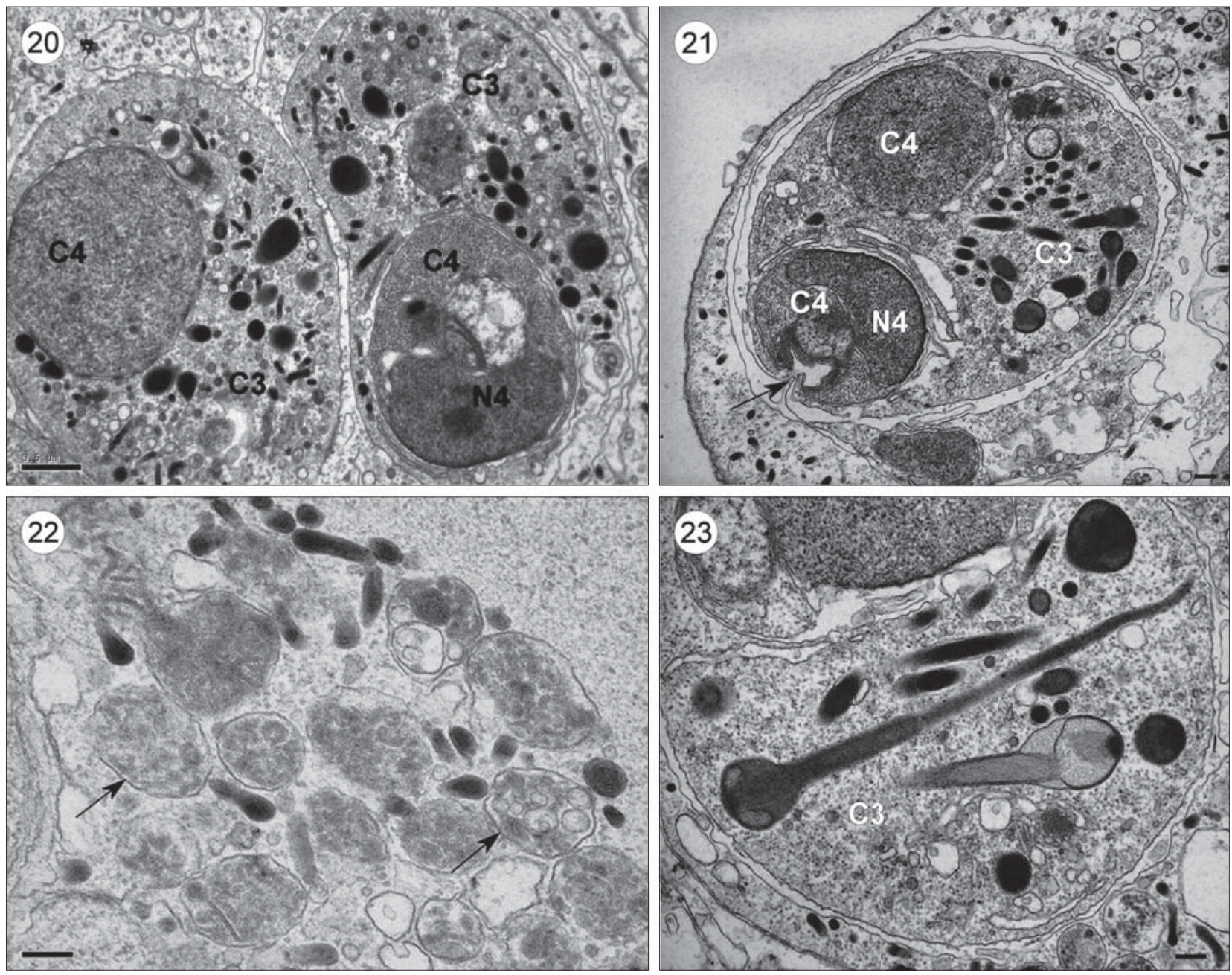

Figs. 20-23. Transmission electron micrographs of Paramarteilia canceri sp. n. infecting Cancer pagurus. Fig. 20. Tertiary cells (C3) with typical haplosporosomes of variable size and shape in the cytoplasm. Quaternary cells (C4) are clearly visible within the tertiary cells and contain a prominent nucleus (N4). Fig. 21. Tertiary cell (C3) with two quaternary cells (C4), one of which contains a typical reniform nucleus (N4). Note the apparent ingestion of plasma membranes by one of the quaternary cell (arrow). Fig. 22. Haplosporogenesis in the tertiary cell involves granular-filled vesicles (multivesicular bodies) (arrows) and the production of bacilliform haplosporosomes. Fig. 23. Numerous bulb-ended haplosporosomes in the cytoplasm of the tertiary cell (C3) at different stages of development. Note the apparent presence of a cortex and medulla in some of the haplosporosomes. Scale bars: Fig. $20=0.5 \mu \mathrm{m}$; Figs. $21-23=200 \mathrm{~nm}$.

nuclear pore (Figs. 23, 26). A mitochondrion with inconspicuous cristae was located in a cup-shaped depression in the nucleus (Fig. 27). Haplosporosomes were absent from the cytoplasm of the quaternary cell. The presence of a centriole close to the nucleus (Fig. 27) suggested that quaternary cells were capable of division. Apparent ingestion of plasma membranes by a quaternary cell (Fig. 21) also suggested a mechanism for release into the primary cell and subsequent division (Fig. 29).

\section{DISCUSSION}

Of the five currently recognised genera within the order Paramyxida, the parasite currently described from Cancer pagurus most closely fits the description of Paramarteilia as defined by Ginsburger-Vogel and Desportes (1979b). Only two other paramyxids containing bicellular spores have been described, the type species of the genus Paramarteilia, P. orchestiae, and Marteilioides branchialis. The latter species only contains a single bicellular spore and can readily be discriminated from the current species on that basis. Additionally, M. branchialis contains between 2 and 6 (rarely 12) secondary cells within the primary cell. Paramarteilia orchestiae however contains two tertiary cells in common with the current species but a greater number of secondary cells (up to 10), compared with a maximum of 3 cells found in the C. pagurus parasite. The secondary cell cytoplasm of the current species has few ribosomes, compared with the cytoplasm of sec- 

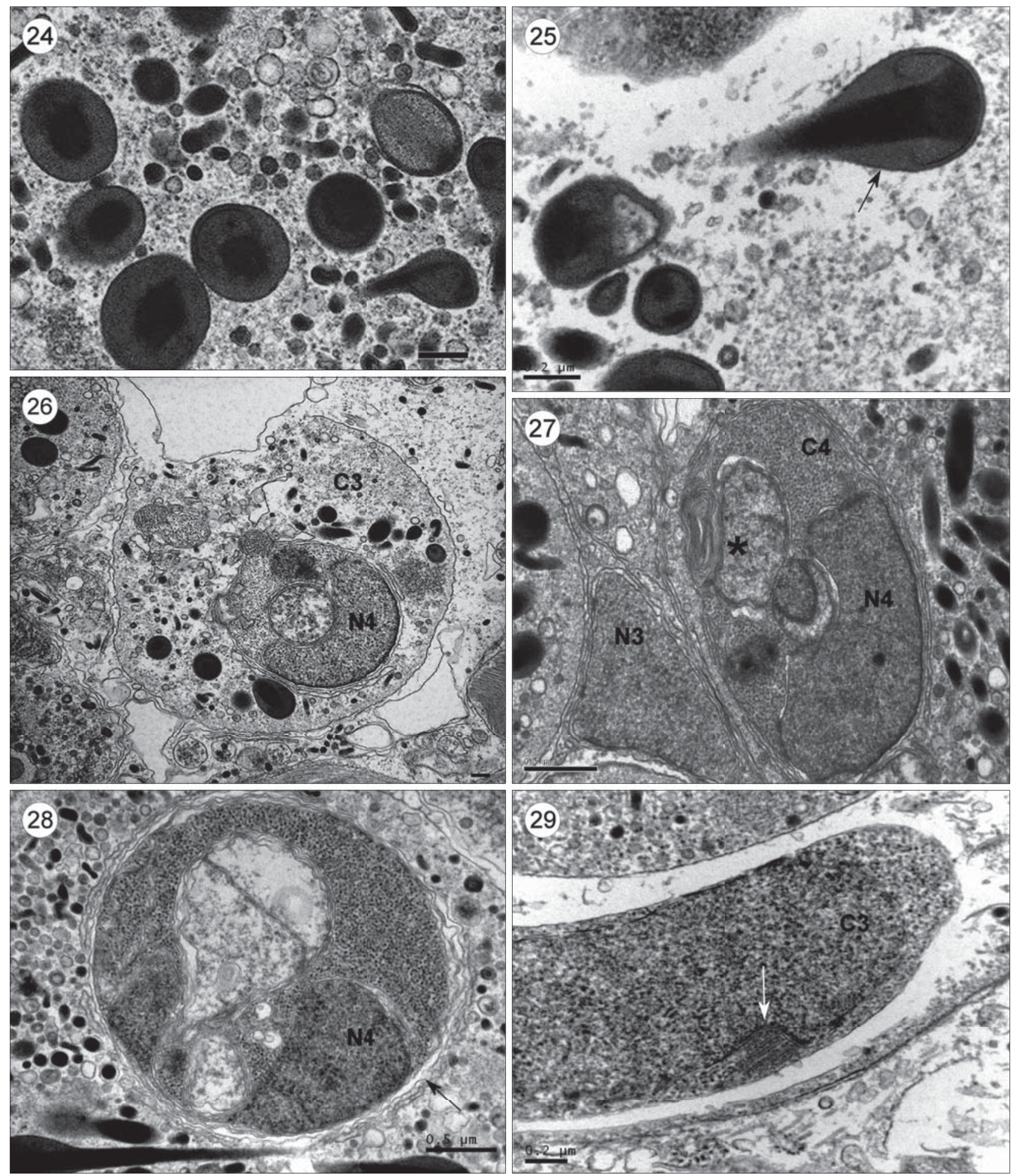

Figs. 24-29. Transmission electron micrographs of Paramarteilia canceri sp. n. infecting Cancer pagurus. Fig. 24. Transverse sections through the bulbous end of large haplosporosomes of the tertiary cell with a noticeable core of electron-dense material present in most. Various-sized vesicles are also present in the cytoplasm. Fig. 25. Cross-section of haplosporosomes of the tertiary cell. Note presence of inner and outer membrane, although the inner membrane appears to be discontinuous in the apex of the haplosporosome (arrow). Fig. 26. Tertiary cell (C3) containing typically spherical quaternary cell with a reniform nucleus (N4). Limited cell contents are present in the cytoplasm of the quaternary cell. Fig. 27. Ovoid quaternary cell (C4) with nucleus (N4) and mitochondrion with inconspicuous cristae $(*)$. Typically triangular nucleus (N3) of the tertiary cell is apparent. Fig. 28. Developing quaternary cell with dense granular cytoplasm (ribosomes), peripheral nucleus (N4) and surrounded by strands of endoplasmic reticulum (arrow). Fig. 29. Microtubules (arrow) present in the cytoplasm of a dividing tertiary cell. Scale bars: Figs. 24-26, $29=200 \mathrm{~nm}$; Fig. $27,28=0.5 \mu \mathrm{m}$. 
ondary cell of $P$. orchestiae, which is rich in ribosomes. Occasionally, pseudopodia-like projections from the plasma membrane of the tertiary cells were apparent, which was not noted in P. orchestiae. Also, the current species is approximately half the size of $P$. orchestiae. Given the difference in the number of secondary cells, differences in cellular contents and overall size we propose the erection of a new species of Paramarteilia, namely $P$. canceri sp. n.

Whilst most members of the Paramyxida occur in specific tissues, the systemic nature of the current parasite suggests a number of routes exist within the host which may exacerbate the pathology and increase mortality rates through multiple organ failure. This may explain the low prevalence of infection observed as heavily infected individuals may readily succumb to infection. Low prevalence may also indicate a geographical range limit for $P$. canceri since other paramyxeans come from areas with higher ambient water temperatures. However, additional surveys for paramyxid parasites and $P$. canceri in particular are required to confirm this. Unlike $P$. orchestiae infections of male Orchestia gammarellus (see Ginsburger-Vogel and Desportes 1979a), there was no evidence of intersex in male or female $C$. pagurus associated with the presence of the parasite.

Current criteria for discriminating genera and species within the order Paramyxida are based on different diagnostic features at the light and ultrastructural level. The first paramyxid to be described, Paramyxa paradoxa Chatton, 1911 from polychaetes, was originally described using light microscopic features and was discriminated from its congeners much later using ultrastructural features (Desportes 1981). The genus Marteilia, accommodating parasites of bivalve molluscs and copepods (Audemard et al. 2002), was erected by Grizel et al. (1974), and discriminated from Paramyxa mainly on light microscopy features. The next genus in the order to be described was Paramarteilia by Ginsburger-Vogel and Desportes (1979b) who used a combination of host (amphipods), the number of secondary cells and the nature of the spore to discriminate this new genus from Marteilia and Paramyxa. Marteilioides, infecting bivalve molluscs was discriminated from others in the order by only a single tricellular spore in the secondary cell (Comps et al. 1986). However, Anderson and Lester (1992) in describing Marteilioides branchialis, amended the genus definition to include parasites that possessed single tricellular or bicellular spores in the secondary cell. Most recently, a fifth genus in the order, Paramyxoides, was described from polychaetes by Larsson and Køie (2005) who suggested that whilst morphologically similar to Paramyxa, the ornamentation of the spore (tertiary cell) and the presence of "haplosporosomes" in two of the four spore cells readily discriminated this parasite from the others in the order.
In order to try to resolve some of the long-standing issues about just two species within the genus Marteilia, Longshaw et al. (2001) used light and ultrastructural features to show that Marteilia species in oysters and mussels could not be readily discriminated. They suggested that the morphological criteria used within the phylum Paramyxea (and thus the order Paramyxida) needed to be re-examined, particularly the use of haplosporosome morphology, which was shown to be variable. Longshaw et al. (2001) proposed that Marteilia maurini Comps, Pichot et Papagianni, 1982 was a junior synonym of M. refringens, which was later confirmed using molecular methods (Berthe et al. 2000), suggesting that mussels and oysters contained different strains of the same parasite.

To date, molecular information has been obtained for Marteilia sydneyi, M. refringens, Marteilioides branchialis and $M$. chungmuensis, reflecting the relative importance of these pathogens in bivalve aquaculture. The molecular data confirm that these species are related, fit well within the phylum and validate the use of morphological characteristics to discriminate the four species within the phylum (Berthe et al. 2000). The 18S rDNA sequence data for Marteilioides chungmuensis and Marteilioides sp. (Kleeman et al. 2002 and Itoh et al. 2003, respectively), showed that these species fall within the genus Marteilia, although these authors did not propose taxonomic revision.

During the current study it became apparent that a review and revision of the genera within the order was necessary in light of new knowledge since the original descriptions. The use of different diagnostic criteria has created confusion in the order. For example, Marteilioides chungmuensis and M. branchialis were grouped in the same genus on the basis of a single secondary cell, which is bicellular in $M$. branchialis but tricellular in M. chungmuensis. However, Marteilia spp. are grouped together on the basis of possession of a variable number of tricellular spores. Uncertainty in taxonomic criteria has caused species to remain undescribed or poorly described (Comps 1976, 1985, Moyer et al. 1993, Norton et al. 1993, López and Darriba 2006, Virvilis and Angelidis 2006). Age-related variability in spore wall morphology and the utilisation of different host taxa by these parasites further restricts the number of suitable characters to discriminate genera and species (Longshaw et al. 2001).

Size and shape of haplosporosomes have also been used to discriminate between species and genera. Whilst these are useful, they should not be used in isolation from other morphological criteria as they can be pleomorphic, varying markedly within a species and overlapping in size range between species. In addition, it is important to use correct terminology when describing the different organelles in paramyxids. Larsson and Køie (2005) suggested that the inclusion bodies in cell 5 of Paramyxoides spores were haplosporosomes, despite lacking a medul- 


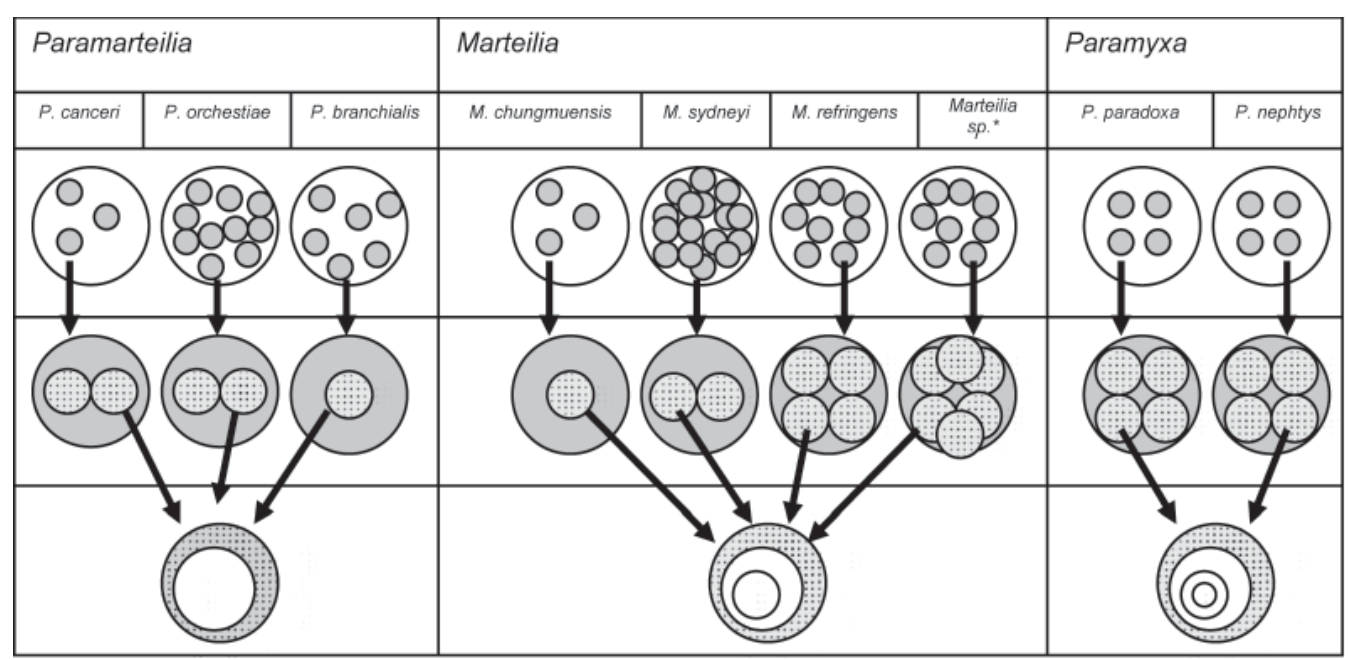

Fig. 30. Proposed classification of the phylum Paramyxea. The main diagnostic feature for each genus is the nature of the spore, being either bi-, tri- or tetracellular. The three proposed genera are shown with representative species in each of the genera. Members of the Paramarteilia are composed of primary cells containing up to 12 secondary cells, each containing either 1 or 2 bicellular spores. Representatives of the Marteilia contain between 3 and 16 secondary cells, each containing between 1 and 6 tricellular spores. Members of the Paramyxa contain 2 to 4 secondary cells, each containing 4 tetracellular spores. Nuclei in each cell are not shown for clarity on the main images, but are illustrated on the key. Where Marteilia sp.* is Marteilia sp. of López and Darriba (2006). Not to scale.

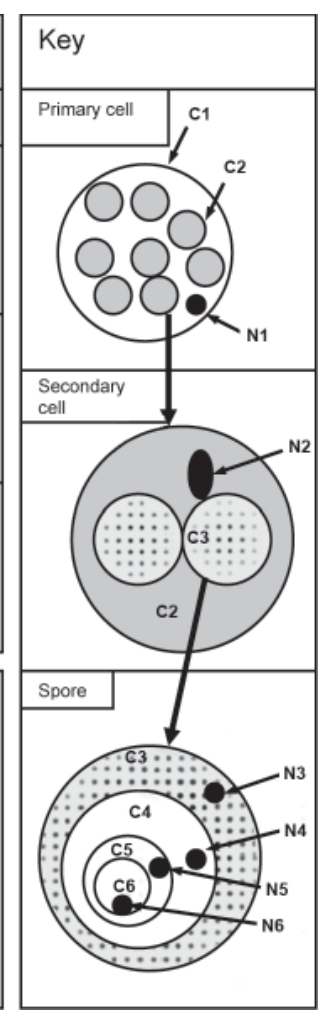

la, typical of haplosporosomes. They may be haplosporosome-like bodies similar to those in a haplosporidian parasite of Carcinus maenas (see Stentiford et al. 2004). Similar structures to those in cell 5 of Paramyxoides nephtys reported by Larsson and Køie (2005) are referred to as "rod-like structures" in cell 4 of Marteilia spp. (Comps 1985, Norton et al. 1993, Longshaw et al. 2001, López and Darriba 2006) and reported by Perkins (1976) as vesicles within the middle sporoplasm cell (C4). Therefore these structures, used by Larsson and Køie (2005) to distinguish the genus Paramyxoides, are probably taxonomically invalid.

In attempting to resolve taxonomic confusion within the order, we considered the number of cells in each genus, since the principal distinguishing characteristics at the genus level include the numbers of spores per secondary cell, the number of cells per spore and the shape of the spores (Larsson and Køie 2005). Initially, the number of cells in the spore distinguishes three genera, those with bicellular spores, those with tricellular spores and then finally those with tetracellular spores (Fig. 30). Further subdivisions to species within these genera then appear to be related initially to the number of spores within the secondary cells and then the number of secondary cells within the primary cell. Whilst reducing the number of genera, this appears to stabilise the order and will facilitate the description of new species within the group. Differences in spore morphology, including spore appendages, may then further discriminate species. The additional use of molecular techniques may elucidate cryptic species and parasite strains within the same species. This is particularly important given the recent reporting of Marteilia refringens in razor clams by López-Flores et al. (2008), which may be conspecific with the Marteilia sp. reported by López and Darriba (2006) which contained up to 6 spores, rather than the expected 4 in $M$. refringens.

We propose suppressing the genus Marteilioides and transferring the type species M. chungmuensis to Marteilia, whilst moving $M$. branchialis to Paramarteilia to take account of the number of cells present in the spore. Similarly, we propose suppressing the genus Paramyxoides since there are insufficient grounds to justify the erection of that genus, particularly given that the organelles reported as haplosporosomes in cell 5 of Paramyxoides are not unique to the genus, the variability existing with the spore morphology and the lack of difference in the number of cells present in the primary, secondary and tertiary cells compared with Paramyxa. The type and only species of the genus, P. nephtys, should be transferred to Paramyxa.

\section{REVISED CLASSIFICATION OF PARAMYXIDA}

\section{Order Paramyxida Chatton, 1911}

Sporulation results from endodyogeny within an amoeboid stem cell that germinates from spores in tissues of invertebrate marine animals. Development characterised by production of offspring cells that remain inside the parent cell. Spores consist of several cells enclosed inside each other. 


\section{Paramyxa Chatton, 1911}

Sporogony by endogenous budding. Amoeboid vegetative stages (primary cell) internally cleave to produce 2 or 4 secondary cells. Sporulation: each secondary cell (sporonts) cleaves to produce 4 tertiary cells (spores) which contain three additional cells so that spores are tetracellular.

Type species: Paramyxa paradoxa Chatton, 1911.

Other species: P. nephtys (Larsson et Køie, 2005) comb. n. (syn. Paramyxoides nephtys).

Marteilia Grizel, Comps, Bonami, Cosserans, Duthoit et Le Pennec, 1974

Sporogony by endogenous budding. Amoeboid vegetative stages (primary cell) internally cleave to produce secondary cells. Sporulation: each secondary cell (sporonts) cleaves internally to produce a variable number of tertiary cells (spores) which contain a further two cells so that spores are tricellular.

Type species: Marteilia refringens Grizel, Comps, Bonami, Cosserans, Duthoit et Le Pennec, 1974.

Other species: M. sydneyi Perkins et Wolf, 1976; M. christenseni Comps, 1983; M. chungmuensis (Comps, Park et Desportes, 1986) comb. n. (syn. Marteilioides chungmuensis).

\section{Paramarteilia Ginsburger-Vogel et Desportes, 1979}

Sporogony by endogenous budding. Amoeboid vegetative stages (primary cell) internally cleave to produce secondary cells. Sporulation: each secondary cell (sporonts) cleaves to produce a variable number of tertiary cells (spores) which contain a single cell so that spores are bicellular.

Type species: Paramarteilia orchestiae GinsburgerVogel et Desportes, 1979.

Other species: P. branchialis (Anderson et Lester, 1992) comb. n. (syn. Marteilioides branchialis); P. canceri sp. n.

\section{Taxonomic summary}

Phylum Cercozoa Cavalier-Smith, 1998

Order Paramyxida Chatton, 1911

Genus Paramarteilia Ginsburger-Vogel et Desportes, 1979

\section{Paramarteilia canceri sp. $n$.}

Specific diagnosis. Primary cell amoeboid and uninucleate containing haplosporosomes in cytoplasm. Early primary cell usually spherical, becoming ovoid as parasite increase in size, measuring up to $15 \mu \mathrm{m}$ along longest axis. Secondary cells formed by internal cleavage contain few ribosomes, a single mitochondrion, are devoid of haplosporosomes and measure approximately 4-6 $\mu \mathrm{m}$. Up to three secondary cells present, containing 1-2 tertiary cells per secondary cell. Tertiary cells spherical measuring approximately $3 \mu \mathrm{m}$ in diameter and contain a single quaternary cell measuring approximately $2 \mu \mathrm{m}$. Haplosporosomes present in cytoplasm of tertiary cells elongate with bulb-like projection at one end.

Type host: Cancer pagurus L. (Crustacea, Decapoda).

Type locality: English Channel, off Portland, Dorset $\left(50^{\circ} 30^{\prime} \mathrm{N}, 2^{\circ} 27^{\prime} \mathrm{W}\right)$.

Site of infection: Systemic throughout animal.

Type material: Syntype slides of histological sections stained with H\&E, wax blocks, EM blocks and uranyl acetate-stained grids, deposited in the Registry of Aquatic Pathology (RAP) held at the Cefas Weymouth Laboratory (Acc. Nos. 884). H\&E-stained syntype slides deposited in the collection of the Institute of Parasitology, Academy of Sciences of the Czech Republic, České Budějovice (Acc. No. IP ProtColl 7).

Etymology: The specific epithet refers to the generic name of the host.

Acknowledgements. The support of the Department for Environment, Food and Rural Affairs (Defra) (contracts FC1137, FC1166, FC1168) is gratefully acknowledged. In addition, we are grateful to the Marine and Fisheries Agency for dispensation to collect undersized crabs.

\section{REFERENCES}

Anderson T.J., Lester R.J.G. 1992: Sporulation of Marteilioides branchialis n. sp. (Paramyxea) in the Sydney rock oyster, Saccostrea commercialis: an electron microscope study. J. Protozool. 39: 502-508.

Audemard C., Le Roux F., Barnaud A., Collins C., Sautour B., Sauriau P.-G., de Montaudouin X., Coustau C., Combes C., Berthe F.C.J. 2002: Needle in a haystack: involvement of the copepod Paracartia grana in the life cycle of the oyster pathogen Marteilia refringens. Parasitology 124: 315-323.

Bateman K.S., Stentiford G.D. 2008: Cancer pagurus bacilliform virus $(\mathrm{CpBV})$ infecting juvenile European edible crabs C. pagurus from UK waters. Dis. Aquat. Org. 79: 147-151.

Berthe F.C.J., Le Roux F., Adlard R.D., Figueras A. 2004: Marteiliosis in molluscs: A review. Aquat. Living Resour. 17: $433-448$.
Berthe F.C.J., Le Roux F., Peyretaillade E., Peyret P., RoDriguez D., Gouy M., Vivarès C.P. 2000: The existence of the phylum Paramyxea Desportes and Perkins, 1990 is validated by the phylogenetic analysis of the Marteilia refringens small subunit ribosomal RNA. J. Eukaryot. Microbiol. 47: 288-293.

Cavalier-Smith T., Chao E.E.-Y. 2003: Phylogeny of Choanozoa, Apusozoa, and other Protozoa and early eukaryote megaevolution. J. Mol. Evol. 56: 540-563.

Сhatton E. 1911: Sur une Cnidosporidie sans cnidoblaste (Paramyха paradoxa, n.g., n.sp.). C.R. Acad. Sci. Paris 152: 631-633.

Comps M. 1976: Marteilia lengehi n. sp., parasite de l'huître Crassostrea cucullata Born. Rev. Trav. Inst. Pêches Marit. 40: 347-349. 
Comps M. 1985: Étude morphologique de Marteilia christenseni sp. n. parasite du lavignon Scrobicularia piperata P. (mollusque pélécypode). Rev. Trav. Inst. Pêches Marit. 47: 99-104.

Comps M., Park M.S., Desportes I. 1986: Étude ultrastructurale de Marteilioides chungmuensis n.g., n.sp. parasite des ovocytes de l'huître Crassostrea gigas Th. Protistologica 22: 279-285.

Comps M., Park M.S., Desportes I. 1987: Fine structure of Marteilioides chungmuensis n. g., n. sp. parasite of the oocytes of the oyster Crassostrea gigas. Aquaculture 67: 264-265.

Comps M., Pichot Y., Papagianni P. 1982: Recherche sur Marteilia maurini n. sp. parasite de la moule Mytilus galloprovincialis Lmk. Rev. Trav. Inst. Pêches Marit. 45: 211-214.

Desportes I. 1981: Étude ultrastructurale de la sporulation de Paramyxa paradoxa Chatton (Paramyxida) parasite de l'annelide polychaete Poecilochaetus serpens. Protistologica 17: 365-386.

Desportes I. 1984: The Paramyxea Levine 1979: an original example of evolution towards multicellularity. Origins Life Evol. Biosph. 13: 343-352.

Desportes I., Lom J. 1981: Affinités de Paramyxa paradoxa Chatton 1911, parasite de Poecilochaetus serpens (Annélide Polychète) avec les Marteiliidae Sprague, parasites d'Huîtres et du Crustacé Orchestia gammarellus. C. R. Acad. Sci. Paris 292: $627-632$.

Desportes I., Perkins F.O. 1990: Phylum Paramyxea. In: J.O. Margulis, M. Corliss, M. Melkonian and D.J. Chapman (Eds.), Handbook of Protoctista. Jones and Bartlett Publishing, Boston, pp. 30-35.

Ginsburger-Vogel T. 1991: Intersexuality in Orchestia mediterranea Costa, 1853, and Orchestia aestuarensis Wildish, 1987 (Amphipoda): a consequence of hybridisation or parasitic infestation? J. Crust. Biol. 11: 530-539.

Ginsburger-Vogel T., Desportes I. 1979a: Structure and biology of Marteilia sp. in the amphipod, Orchestia gammarellus. Mar. Fish. Rev. 41: 3-7.

Ginsburger-Vogel T., Desportes I. 1979b: Étude ultrastructurale de la sporulation de Paramarteilia orchestiae gen. n., sp. n., parasite de l'amphipode Orchestia gammarellus (Pallas). J. Protozool. 26: 390-403.

Grizel H., Comps M., Bonami J.R., Cousserans F., Duthoit J.L., Le Pennec M.A. 1974: Recherche sur l'agent de la maladie de la glande digestive de Ostrea edulis Linné. Sci. Pêche 240: 7-29.

Itoh N., Oda T., Yoshinaga T., Ogawa K. 2003: Isolation and 18S ribosomal DNA gene sequences of Marteilioides chungmuensis (Paramyxea), an ovarian parasite of the Pacific oyster Crassostrea gigas. Dis. Aquat. Org. 54: 163-169.

Kleeman S.N., Adlard R.D., Lester R.J.G. 2002: Detection of the initial infective stages of the protozoan parasite Marteilia sydneyi in Saccostrea glomerata and their development through to sporogenesis. Int. J. Parasitol. 32: 767-784.

Larsson J.I.R., KøIE M. 2005: Ultrastructural study and description of Paramyxoides nephtys gen. n., sp. n. a parasite of Nephtys caeca (Fabricius, 1780) (Polychaeta: Nephtyidae). Acta Protozool. 44: 175-187.

Received 9 March 2009
Longshaw M., Feist S.W., Matthews R.A., Figueras A. 2001: Ultrastructural characterisation of Marteilia species (Paramyxea) from Ostrea edulis, Mytilus edulis and Mytilus galloprovincialis in Europe. Dis. Aquat. Org. 44: 137-142.

López C., Darriba S. 2006: Presence of Marteilia sp. (Paramyxea) in the razor clam Solen marginatus (Pennántt, 1777) in Galicia (NW Spain). J. Invertebr. Pathol. 92: 109-111.

López-Flores I., Garrido-Ramos M.A., de la Herran R., RuizRejón C., Ruiz-Rejón M., Navas J.I. 2008: Identification of Marteilia refringens infecting the razor clam Solen marginatus by PCR and in situ hybridization Mol. Cell. Probes 22: 151-155.

Moyer M.A., Blake N.J., Arnold W.S. 1993: An ascetosporan disease causing mass mortality in the Atlantic calico scallop, Argopecten gibbus (Linnaeus, 1758). J. Shellfish Res. 12: 305-310.

Norton J.H., Perkins F.P., Ledua E. 1993: Marteilia-like infection in a giant clam, Tridacna maxima, in Fiji. J. Invertebr. Pathol. 61: 328-330.

OIE 2006: Manual of Diagnostic Tests for Aquatic Animals. Fifth edition. World Organisation for Animal Health, Paris, 469 pp.

PERKIns F.O. 1976: Ultrastructure of sporulation in the European flat oyster pathogen, Marteila refringens - taxonomic implications. J. Protozool. 23: 64-74.

PERKINS F.O. 1979: Cell structure of shellfish pathogens and hyperparasites in the genera Minchinia, Urosporidium, Haplosporidium, and Marteilia - taxonomic implications. Mar. Fish. Rev. 41: 25-37.

Perkins F.O., Wolf P.H. 1976: Fine structure of Marteilia sydneyi sp. n. - haplosporidian pathogen of Australian oysters. J. Parasitol. 62: 528-538.

ReYNOLDS E.S. 1963: The use of lead citrate at high $\mathrm{pH}$ as an electron-opaque stain in electron microscopy. J. Cell Biol. 17: 208-212.

Stentiford G.D. 2008: Diseases of the European edible crab (Cancer pagurus): a review. ICES J. Mar. Sci. 65: 1578-1592.

Stentiford G.D., Bateman K.S., Longshaw M., Feist S.W. 2007: Enterospora canceri n. gen., n. sp., intranuclear within the hepatopancreatocytes of the European edible crab Cancer pagurus. Dis. Aquat. Org. 75: 61-72.

Stentiford G.D., Evans M., Bateman K., Feist S.W. 2003: Coinfection by a yeast-like organism in Hematodinium-infected European edible crabs (Cancer pagurus) and velvet swimming crabs (Necora puber) from the English Channel. Dis. Aquat. Org. 54: 195-202.

Stentiford G.D., Feist S.W., Bateman K.S., Hine P.M. 2004: A haemolymph parasite of the shore crab Carcinus maenas: pathology, ultrastructure and observations on crustacean haplosporidians. Dis. Aquat. Org. 59: 57-68.

Stentiford G.D., Green M., Bateman K.S., Small H.J., Neil D.M., FeIST S.W. 2002: Infection by a Hematodinium-like parasitic dinoflagellate causes Pink Crab Disease (PCD) in the edible crab Cancer pagurus. J. Invertebr. Pathol. 79: 179-191.

Virvilis C., Angelidis P. 2006: Presence of the parasite Marteilia sp. in the flat oyster (Ostrea edulis L.) in Greece. Aquaculture 259: $1-5$.

Accepted 14 May 2009 